\title{
Clinico-epidemiological profile of COVID-19 cases: Our experiences
}

\author{
Rajiva $^{1}$, Muruganantham $\mathrm{M}^{2}$, Gautam Mukherjee ${ }^{3}$, Singh PMP $^{3,}$, Aaditya Saxena ${ }^{4}$, Sridhar Chary ${ }^{4}$ and Sandeep Singh Mahar ${ }^{4}$ \\ ${ }^{1}$ Formerly Colonel Health and Senior Adviser Community Medicine, Headquarters Central Command (Medical Branch), P.O. Dilkusha, \\ Lucknow, 226002, India \\ ${ }^{2}$ Department of Anaesthesiology, Armed Forces Medical Services, India \\ ${ }^{3}$ Department of Community Medicine, Armed Forces Medical Services, India \\ ${ }^{4}$ Medical Officer, AFMS, India
}

\section{Abstract}

Introduction: A novel beta coronavirus, which was named as severe acute respiratory syndrome coronavirus 2 (SARS-CoV-2), was identified to be the causative organism of coronavirus disease (COVID-19).

Aims: To study the clinico-epidemiological profile of hospitalised COVID-19 cases in an urban area.

Material and methods: The workers carried out a cross sectional descriptive study. Period of the study was 01 April 2020 to 31 December 2020. Detailed epidemiological, clinical, laboratory and radiological data was obtained from each case. Above data in respect of 332 cases of COVID-19 was obtained.

Results: Mean age of the cases was 45.68 years. Two hundred and sixty four $(79.52 \%)$ cases were males, while sixty eight $(20.48 \%)$ were females. Two hundred and thirty five $(70.78 \%)$ gave history of fever. Mean duration of hospitalisation was 9.41 days. Thirty six $(10.84 \%)$ cases were required to be placed on ventilator for various periods of time. Eighty four $(25.30 \%)$ cases required to be administered oxygen for various periods of time. There were seven $(2.10 \%)$ fatalities.

Conclusion: The workers recommend that more research be carried out to identify various agent, host and environmental factors which may play a significant role in the pathogenesis of severe and fatal infections.

Keywords: clinico epidemiological; COVID-19; SARS-CoV- 2

\begin{abstract}
*Corresponding author: Maninder Pal Singh Pardal, Mandara A2-504, survey No.19/194 Nyati Epitome, Opposite Corinthian Club, Mohammadwadi, Pune City, India. Email: ltcolpmpsingh@ yahoo.com
\end{abstract}

Received 3 May 2021; Revised 25 May 2021; Accepted 4 June 2021; Published 15 June 2021

Citation: Rajiva, Muruganantham M, Mukherjee G, Singh PMP, Saxena A, Chary S, Mahar SS. Clinico-epidemiological profile of
COVID-19 cases: Our experiences. J Med Sci Res. 2021; 9(3):155161. DOI: http://dx.doi.org/10.17727/JMSR.2021/9-22

Copyright: (C) 2021 Rajiva et al. Published by KIMS Foundation and Research Center. This is an open-access article distributed under the terms of the Creative Commons Attribution License, which permits unrestricted use, distribution, and reproduction in any medium, provided the original author and source are credited. 


\section{Introduction}

A novel beta coronavirus, which was named as severe acute respiratory syndrome coronavirus 2 (SARS$\mathrm{CoV}-2$ ), was identified to be the causative organism of coronavirus disease (COVID-19), a newly emerging zoonotic disease, in the city of Wuhan, located in the Hubei province of China in 2019 [1-6].

The World Health Organization (WHO) declared this outbreak as a global public health emergency of international concern on January 30,2020 . Since the outbreak, of COVID-19, the disease has spread worldwide; and the number of infected cases has grown exponentially. $[7,8]$.

\section{Aims \& objectives}

To study the clinico-epidemiological profile of hospitalised COVID-19 cases in an urban area. (a) To determine whether there exists an association between Diabetes Mellitus and risk of developing severe COVID-19, (b) To determine whether there exists an association between Diabetes Mellitus and risk of mortality due to COVID-19, (c) To determine whether there exists an association between other comorbidities and risk of developing severe COVID19, (d) To determine whether there exists an association between other comorbidities and risk of mortality due to COVID-19.

\section{Material and methods}

The workers carried out a cross sectional descriptive study. Period of the study was 01 April 2020 to 31 December 2020. The study was carried out across several urbanareasin India. Detailed epidemiological, clinical, laboratory and radiological data pertaining to date of onset of symptoms, date of admission, movement history during the known incubation period, history of having had contact with a known COVID-19 positive case, whether individual was under quarantine or not when tested for COVID-19, details of various investigations carried out during the course of hospitalisation and other relevant data was obtained from each case. The cases were sorted as mild, moderate, and severe COVID-19 based on the SpO2 and oxygen requirement [9]. Above data in respect of 332 cases of COVID-19 was obtained.

All the above data was obtained as part of routine surveillance of the COVID-19 pandemic situation. The study team thoroughly reviewed all the cases which occurred during the period of study. A detailed clinical and epidemiological history was elicited. Only cases confirmed to be COVID-19 by reverse transcription polymerase chain reaction (RT-PCR) and admitted to the hospital in consonance with the local policy were considered. The entire data obtained pertaining to all the cases was unlinked and anonymous. Ethical clearance from the institutional ethical committee was obtained prior to the conduct of the study.

The data was entered into an MS excel file. Data was subject to appropriate statistical tests. Quantitative variables were described using mean, median, minimum, maximum, and standard deviation and SD and qualitative variables were described using proportion. On bivariate analysis association between the variables were assessed using chi square test and the adjusted and unadjusted OR were assessed along with 95\% confidence interval. All variables which were significant were included in the multivariate logistic regression to predict the association of the factors with severity as well as mortality associated with COVID-19. All the tests were two tailed; and the significance was set at $5 \%$. $P$ value less than 0.05 was considered statistically significant. Statistical package used was SPSS 23.0.

\section{Results \\ Clinical profile}

Mean age of the cases was 45.68 years (Median 45 years, Standard deviation 16.24 years, minimum 3 and maximum 88 years). Two hundred and sixty four $(79.52 \%)$ cases were males, while sixty eight (20.48\%) were females. Two hundred and thirty five $(70.78 \%)$ gave history of fever. Coryza, cough and headache were observed in thirty $(9.03 \%)$, one hundred and seventy one $(51.50 \%)$ and seventy eight $(23.49 \%)$ cases respectively. Ninety three cases $(28.01 \%)$ experienced breathing difficulty to some extent. Bodyache, malaise and diarrhoea were observed in twenty five (7.53\%), twenty one $(6.32 \%)$ and nineteen $(5.72 \%)$ of the cases respectively. Among the uncommon symptoms were joint pain and myalgia, haemoptysis, anosmia, pain chest, vomiting, and pain abdomen, which were seen in forty four (13.25\%), eight $(2.40 \%)$, seven (2.10), six $(1.80 \%)$, five $(1.50 \%)$ and one $(0.30 \%)$ respectively. Only two cases $(0.60 \%)$ case were totally asymptomatic. 
Sex and age wise distribution of the cases is tabulated in Table 1.

Table 1: Sex and age wise distribution of cases.

\begin{tabular}{|lccc|}
\hline \multirow{2}{*}{ Age (Yrs) } & \multicolumn{2}{c}{ Sex } & Total (\%) \\
\cline { 2 - 3 } & Male (\%) & Female (\%) & \\
\hline $20-29$ & $6(1.80)$ & $6(1.80)$ & $12(3.61)$ \\
$30-39$ & $38(11.44)$ & $9(2.71)$ & $47(14.15)$ \\
$40-49$ & $70(21.08)$ & $5(1.50)$ & $75(22.59)$ \\
$50-59$ & $51(15.36)$ & $11(3.31)$ & $62(18.67)$ \\
$60-69$ & $46(13.85)$ & $13(3.91)$ & $59(17.77)$ \\
$>70$ & $34(10.24)$ & $14(4.21)$ & $48(14.45)$ \\
Total (\%) & $264(79.52)$ & $68(20.48)$ & $332(100 \%)$ \\
\hline
\end{tabular}

Mean duration from onset of symptoms to diagnosis was 1.8 days (median 4 days, standard deviation 1.62 days, minimum 1 day and maximum 7 days), resulting in a left skewed deviation. Mean duration from diagnosis to admission in hospital was 1.13 days (median 1, standard deviation 1.95 days, minimum 0 day and maximum 13 days). Mean duration of hospitalisation was 9.41 days (median 9 days, standard deviation 5.49 days, minimum 1 day and maximum 36 days).

Thirty six (10.84\%) cases were required to be placed on ventilator for various periods of time. Eighty four (25.30\%) cases required to be administered oxygen for various periods of time. There were seven (2.10\%) fatalities. All the remaining three hundred and twenty five (97.89\%) cases recovered. Based on above data it can be concluded that approximately seventy five percent of cases are mild to moderate, fifteen percent are severe, and ten percent critical.

\section{Laboratory and other investigations profile}

X-ray chest in respect of all the cases except seven $(2.10 \%)$ was unremarkable. In these seven cases, there was some evidence of pneumonia, which was confirmed by computerized tomography (CT) scan. CT scan was not carried out in the remaining cases due to resource constraints. The pneumonia in all the cases resolved after five to seven days.

Out of 332 cases who were RT-PCR positive for COVID-19 at the time of admission, repeat RT-PCR was carried out in seven $(2.10 \%)$ cases. All the seven cases (100\%) were RT-PCR positive for COVID-19 during the repeat test. Mean duration between the first and the second RT-PCR test was 10.38 days (standard deviation 0.74 days, minimum 10 days and maximum 12 days). RT-PCR for COVID-19 was repeated for a third time in 7 (2.10\%) out of 332 cases, of which 4 (57.14\%) were positive. Duration between the second and third RT-PCR test was seven days in all the cases. Fourth RT-PCR test for COVID19 was carried out in $4(1.20 \%)$ of cases, of which all were negative. Duration between the third and fourth RT-PCR test was seven days in all the cases.

Results of haemoglobin, total leucocyte count, platelet count, liver function tests, renal function tests, serum electrolytes; and inflammatory markers like CRP, LDH, serum ferritin and D Dimer are tabulated in Table 2.

Differential leucocyte count was within normal limits in all the cases. Other inflammatory markers like procalcitonin and Interleukin 6 were not carried out due to resource constraints.

\section{COVID-19 and other comorbidities}

Commonest comorbidity observed among the cases was diabetes which was seen in sixty seven (20.18\%) of cases. Ischaemic heart disease, bronchial asthma and chronic obstructive pulmonary disease were observed in twelve (3.61\%), nine $(2.71 \%)$ and five $(1.50 \%)$ cases respectively.

On bivariate analysis significant association was found between patients with Diabetes Mellitus and severe COVID-19 [OR - 3.84 (1.864-7.922)], age more than 70 years and severe COVID-19 [OR - 4.6 (1.9-11.09)], asthma and severe COVID-19 [OR 4.394 (1.049-18.396)].

A statistically significant association was also found between female gender and death [OR - 5.44 (1.1924.90)], age more than 70 years and death as an outcome [OR - 31.35 (5.78-170.21)] and severe COVID-19 and death as an outcome [OR - 59 (6.87506.56)].

When the data was analysed by logistic regression significant association was seen with diabetes mellitus, Age $>70$ years and Bronchial Asthma with severity of COVID-19 infection. The findings are summarised in Tables 3, 4 and 5 below. 
Table 2: Results of haemoglobin, total leucocyte count, platelet count, liver function tests, renal function tests, serum electrolytes; and inflammatory markers like CRP, LDH, serum ferritin and D Dimer.

\begin{tabular}{|c|c|c|c|c|c|c|c|c|c|}
\hline \multirow[t]{2}{*}{ Test } & \multicolumn{3}{|c|}{ Mean, Median (Min, Max, Std deviation) } & \multicolumn{3}{|c|}{$\begin{array}{c}\text { Number of cases in whom test car- } \\
\text { ried out (\%) }\end{array}$} & \multicolumn{3}{|c|}{$\begin{array}{c}\text { Number of cases in whom result } \\
\text { was deranged (\%) (Out of those in } \\
\text { whom test was carried out) }\end{array}$} \\
\hline & Mild & Moderate & Severe & Mild & Moderate & Severe & Mild & Moderate & Severe \\
\hline $\mathrm{Hb}(\mathrm{gm} \%)$ & $\begin{array}{l}13.56,13.5 \\
(9.5,16.5 \\
1.23)\end{array}$ & $\begin{array}{c}11.96,12.2 \\
(6.4,15.8 \\
1.93)\end{array}$ & $\begin{array}{c}11.41,11.7 \\
(6.4,14.7 \\
2.08)\end{array}$ & $\begin{array}{c}212 \\
(100 \%)\end{array}$ & $84(100 \%)$ & $\begin{array}{c}36 \\
(100)\end{array}$ & $10(4.71)$ & $8(9.52)$ & $\begin{array}{c}15 \\
(41.66)\end{array}$ \\
\hline TLC & $\begin{array}{c}5410.87 \\
5250(3000 \\
14000 \\
1647.01)\end{array}$ & $\begin{array}{c}11750.95 \\
10750 \\
(3300 \\
37900, \\
5323.67)\end{array}$ & $\begin{array}{c}12641.67 \\
11000 \\
(4400, \\
37900, \\
6640.71)\end{array}$ & $\begin{array}{c}212 \\
(100 \%)\end{array}$ & $84(100 \%)$ & $\begin{array}{c}36 \\
(100)\end{array}$ & $6(2.83)$ & $\begin{array}{c}15 \\
(17.85)\end{array}$ & $\begin{array}{c}17 \\
(47.22)\end{array}$ \\
\hline $\begin{array}{l}\text { Platelet } \\
\text { count (/ } \\
\left.\mathrm{mm}^{3}\right)\end{array}$ & $\begin{array}{c}185478, \\
182000 \\
(100000, \\
251000, \\
22257)\end{array}$ & $\begin{array}{c}182048.19 \\
168000 \\
(33000 \\
570000 \\
110604.43)\end{array}$ & $\begin{array}{c}192428.57 \\
174000 \\
(35000 \\
570000 \\
116236.65)\end{array}$ & $\begin{array}{c}212 \\
(100 \%)\end{array}$ & $84(100 \%)$ & $\begin{array}{c}36 \\
(100)\end{array}$ & $0(0)$ & $\begin{array}{c}12 \\
(14.28)\end{array}$ & $\begin{array}{c}19 \\
(52.77)\end{array}$ \\
\hline \multicolumn{10}{|c|}{ Liver function tests } \\
\hline $\begin{array}{l}\text { Total bili- } \\
\text { rubin }\end{array}$ & $\begin{array}{c}0.6,0.85 \\
(0.05,1.1 \\
0.23)\end{array}$ & $\begin{array}{c}07,0.66 \\
(0.05,1.56 \\
0.30)\end{array}$ & $\begin{array}{l}0.77,0.76 \\
(0.05 \\
1.56,0.36)\end{array}$ & $\begin{array}{c}79 \\
(37.26)\end{array}$ & $84(100 \%)$ & $\begin{array}{c}36 \\
(100)\end{array}$ & $7(8.86)$ & $\begin{array}{c}11 \\
(13.09)\end{array}$ & $\begin{array}{c}8 \\
(22.22)\end{array}$ \\
\hline $\begin{array}{l}\text { Conjugated } \\
\text { bilirubin }\end{array}$ & $\begin{array}{c}0.25,0.11 \\
(0.01,0.54 \\
0.10)\end{array}$ & $\begin{array}{c}0.28,0.27 \\
(0.04,0.62 \\
0.11)\end{array}$ & $\begin{array}{c}0.31,0.31 \\
(0.04,0.62 \\
0.12)\end{array}$ & $\begin{array}{c}79 \\
(37.26)\end{array}$ & $84(100 \%)$ & $\begin{array}{c}36 \\
(100)\end{array}$ & $7(8.86)$ & $\begin{array}{c}11 \\
(13.09)\end{array}$ & $\begin{array}{c}8 \\
(22.22)\end{array}$ \\
\hline SGOT & $\begin{array}{c}45.33, \\
42.69 \\
(08.66, \\
189.66, \\
42.15)\end{array}$ & $\begin{array}{c}75.71 \\
55.9(17.5 \\
257.9 \\
55.75)\end{array}$ & $\begin{array}{c}77.05,54.3 \\
(25,204.61 \\
50.94)\end{array}$ & $\begin{array}{c}79 \\
(37.26)\end{array}$ & $84(100 \%)$ & $\begin{array}{c}36 \\
(100)\end{array}$ & $0(0)$ & $0(0)$ & $0(0)$ \\
\hline SGPT & $\begin{array}{c}53.25 \\
39.60(04.7 \\
324.1 \\
50.40\end{array}$ & $\begin{array}{c}71.9,50.15 \\
(13,324.1 \\
65.66)\end{array}$ & $\begin{array}{c}68.39,55 \\
(16.8,324.1 \\
58.04)\end{array}$ & $\begin{array}{c}79 \\
(37.26)\end{array}$ & $84(100 \%)$ & $\begin{array}{c}36 \\
(100)\end{array}$ & $28(13.2)$ & $\begin{array}{c}54 \\
(64.28)\end{array}$ & $\begin{array}{c}24 \\
(66.66)\end{array}$ \\
\hline $\begin{array}{l}\text { Alkaline } \\
\text { phos- } \\
\text { phatase }\end{array}$ & $\begin{array}{c}86.88, \\
88.23 \\
(08.22 \\
211.23 \\
45.69\end{array}$ & $\begin{array}{c}106.01 \\
89.38 \\
(12.4 \\
292.1 \\
56.95)\end{array}$ & $\begin{array}{l}120.6,124.9 \\
(12.9,330.5 \\
63.63)\end{array}$ & $\begin{array}{c}79 \\
(37.26)\end{array}$ & $84(100 \%)$ & $\begin{array}{c}36 \\
(100)\end{array}$ & $1(1.26)$ & $\begin{array}{c}11 \\
(13.09)\end{array}$ & $\begin{array}{c}2 \\
(5.55)\end{array}$ \\
\hline \multicolumn{10}{|c|}{ Renal function tests } \\
\hline Blood urea & $\begin{array}{c}30.36 \\
27.84(9.73 \\
38.49 \\
18.54)\end{array}$ & $\begin{array}{c}40.77,34.5 \\
(12.69 \\
133.2 \\
23.95)\end{array}$ & $\begin{array}{c}46.76,37.8 \\
13.5,133.2 \\
25.44)\end{array}$ & $\begin{array}{c}80 \\
(37.73)\end{array}$ & $84(100 \%)$ & $\begin{array}{c}36 \\
(100)\end{array}$ & $0(0)$ & $\begin{array}{c}19 \\
(22.61)\end{array}$ & $\begin{array}{c}12 \\
(33.33)\end{array}$ \\
\hline $\begin{array}{l}\text { Serum } \\
\text { creatinine }\end{array}$ & $\begin{array}{c}1.07,1.00 \\
(0.15,3.66, \\
0.45)\end{array}$ & $\begin{array}{c}1.19,1.1 \\
(0.21,5.27 \\
0.66)\end{array}$ & $\begin{array}{c}1.28,1.16 \\
0.3,5.27 \\
0.83)\end{array}$ & $\begin{array}{c}85 \\
(40.09)\end{array}$ & $84(100 \%)$ & $\begin{array}{c}36 \\
(100)\end{array}$ & $14(16.47)$ & $\begin{array}{c}27 \\
(32.14)\end{array}$ & $\begin{array}{c}16 \\
(44.44)\end{array}$ \\
\hline \multicolumn{10}{|c|}{ Serum electrolytes } \\
\hline Sodium & $\begin{array}{c}135.72 \\
136.23 \\
(109.3,149 \\
04.98)\end{array}$ & $\begin{array}{c}138.87 \\
138(126.8, \\
155,5.58)\end{array}$ & $\begin{array}{c}138.33 \\
133.6 \\
(131.5,155 \\
5.40)\end{array}$ & $\begin{array}{c}87 \\
(41.03)\end{array}$ & $84(100 \%)$ & $\begin{array}{c}36 \\
(100)\end{array}$ & $0(0)$ & $0(0)$ & $0(0)$ \\
\hline Potassium & $\begin{array}{c}4.36,4.00 \\
(3.15 \\
15.36,1.08)\end{array}$ & $\begin{array}{c}4.62,4.28 \\
(3.2,18.16 \\
1.73)\end{array}$ & $\begin{array}{l}4.69,4.6 \\
(3.32 .7 \\
0.81)\end{array}$ & $\begin{array}{c}87 \\
(41.03)\end{array}$ & $84(100 \%)$ & $\begin{array}{c}36 \\
(100)\end{array}$ & $84(96.55)$ & $\begin{array}{c}78 \\
(92.85)\end{array}$ & $\begin{array}{c}32 \\
(88.88)\end{array}$ \\
\hline
\end{tabular}




\begin{tabular}{|c|c|c|c|c|c|c|c|c|c|}
\hline Chloride & $\begin{array}{c}103.98 \\
104.25 \\
(101.22 \\
118.4,6.66)\end{array}$ & $\begin{array}{c}104.43 \\
104.65 \\
(94.1 \\
118.4 \\
5.48)\end{array}$ & $\begin{array}{l}101.36 \\
103.65 \\
(96.18 \\
112.8)\end{array}$ & $\begin{array}{c}87 \\
(41.03)\end{array}$ & $84(100 \%)$ & $\begin{array}{c}36 \\
(100)\end{array}$ & $0(0)$ & $0(0)$ & $0(0)$ \\
\hline CRP (mg\%) & $\begin{array}{c}05.67,4.98 \\
(0.5,29 \\
6.36)\end{array}$ & $\begin{array}{c}10.32,8.13 \\
(1.22,41 \\
8.02)\end{array}$ & $\begin{array}{c}13.04,10.44 \\
(1.35,41 \\
9.36)\end{array}$ & $\begin{array}{c}26 \\
(12.26)\end{array}$ & $84(100 \%)$ & $\begin{array}{c}36 \\
(100)\end{array}$ & 23 (88.46) & $84(100)$ & $\begin{array}{c}36 \\
(100)\end{array}$ \\
\hline $\begin{array}{l}\text { LDH (IU/ } \\
\text { litre) }\end{array}$ & $\begin{array}{c}530.25 \\
536.19 \\
(336.39 \\
1984.99 \\
298.71)\end{array}$ & $\begin{array}{c}841.4 \\
740.1 \\
(424.1 \\
1482.1 \\
358.06)\end{array}$ & $\begin{array}{c}929.83 \\
802.1 \\
(588,1479, \\
372.89)\end{array}$ & $10(4.71)$ & $12(14.28)$ & $\begin{array}{c}10 \\
(27.77)\end{array}$ & 07 (70) & $12(100)$ & $\begin{array}{c}10 \\
(100)\end{array}$ \\
\hline $\begin{array}{l}\text { Serum fer- } \\
\text { ritin (ng/ } \\
\text { ml) }\end{array}$ & $\begin{array}{c}288.75 \\
207.6 \\
(49.57 \\
1297.8, \\
253)\end{array}$ & $\begin{array}{c}807.03,451 \\
(0.4,3050 \\
918.85)\end{array}$ & $\begin{array}{c}747.66, \\
295(0.4 \\
3000.10 \\
1022.49)\end{array}$ & $\begin{array}{c}44 \\
(20.75)\end{array}$ & $84(100)$ & $\begin{array}{c}36 \\
(100)\end{array}$ & $31(70.45)$ & $\begin{array}{c}38 \\
(45.23)\end{array}$ & $\begin{array}{c}15 \\
(41.66)\end{array}$ \\
\hline $\begin{array}{l}\text { D Dimer } \\
(\mathrm{mcg} / \mathrm{ml})\end{array}$ & $\begin{array}{c}5.25,1.45 \\
(0.03 \\
74.76 \\
11.08)\end{array}$ & $\begin{array}{c}975.23 \\
382.9 \\
(33.2 \\
7935 \\
1457.5)\end{array}$ & $\begin{array}{c}922.84 \\
448.6(33.2 \\
4423.7 \\
1067.6)\end{array}$ & $\begin{array}{c}90 \\
(42.45)\end{array}$ & $84(100)$ & $\begin{array}{c}36 \\
(100)\end{array}$ & 84 (93.33) & $\begin{array}{c}71 \\
(84.52)\end{array}$ & $\begin{array}{c}31 \\
(86.11)\end{array}$ \\
\hline
\end{tabular}

Table 3: Bivariate analysis of severe COVID-19 by different independent variables.

\begin{tabular}{|c|c|c|c|c|c|}
\hline & & \multicolumn{4}{|c|}{ Severe COVID-19 } \\
\hline & & Yes & No & $O R$ & $C I$ \\
\hline \multirow{2}{*}{$\begin{array}{l}\text { Diabetes } \\
\text { mellitus }\end{array}$} & Yes & 16 & 51 & \multirow{2}{*}{3.84} & \multirow{2}{*}{$\begin{array}{l}1.864- \\
7.922\end{array}$} \\
\hline & No & 20 & 245 & & \\
\hline \multirow[t]{2}{*}{ Sex } & Male & 27 & 237 & \multirow{2}{*}{0.747} & \multirow{2}{*}{$\begin{array}{c}0.333- \\
1.673\end{array}$} \\
\hline & Female & 9 & 59 & & \\
\hline \multirow[t]{2}{*}{ Age group } & $>70$ & 9 & 20 & \multirow{2}{*}{4.6} & \multirow{2}{*}{$\begin{array}{c}1.9- \\
11.09\end{array}$} \\
\hline & $<70$ & 27 & 276 & & \\
\hline \multirow[t]{2}{*}{ COPD } & Yes & 1 & 4 & \multirow{2}{*}{2.086} & \multirow{2}{*}{$\begin{array}{l}0.227- \\
19.188\end{array}$} \\
\hline & No & 35 & 292 & & \\
\hline \multirow[t]{2}{*}{ Asthma } & Yes & 3 & 6 & \multirow{2}{*}{4.394} & \multirow{2}{*}{$\begin{array}{l}1.049- \\
18.396\end{array}$} \\
\hline & No & 33 & 290 & & \\
\hline \multirow[t]{2}{*}{ IHD/ CAD } & Yes & 0 & 12 & & \\
\hline & No & 36 & 284 & & \\
\hline
\end{tabular}

\section{Epidemiological profile}

Out of three hundred and thirty two cases none of the cases had history of travel abroad, while eighty (24.09\%) gave history of travel within India. Thirty two $(9.63 \%)$ gave history of contact with a positive case of COVID-19. Twenty eight (8.43\%) cases were under quarantine when they underwent RT-PCR test for SARS nCoV2. Three hundred three (91.26\%) were symptomatic and had self-reported for testing, while twenty seven (8.13\%) were symptomatic contacts of confirmed COVID-19 cases.

Table 4: Bivariate analysis of age more than 70 years and outcome (death/ discharge), diabetes mellitus and final outcome (death/ discharge); and Severe COVID-19 and final outcome (death/ discharge).

\begin{tabular}{|c|c|c|c|c|c|}
\hline & & \multicolumn{4}{|c|}{ Final Outcome } \\
\hline & & Death & Discharge & $O R$ & $C I$ \\
\hline \multirow[t]{2}{*}{ Sex } & Female & 4 & 64 & \multirow{2}{*}{5.44} & \multirow{2}{*}{$\begin{array}{l}1.19- \\
24.90\end{array}$} \\
\hline & Male & 3 & 261 & & \\
\hline \multirow{2}{*}{$\begin{array}{l}\text { Age } \\
\text { group }\end{array}$} & $>70$ & 5 & 24 & \multirow{2}{*}{31.35} & \multirow{2}{*}{$\begin{array}{c}5.78- \\
170.21\end{array}$} \\
\hline & $<70$ & 2 & 301 & & \\
\hline \multirow{2}{*}{$\begin{array}{l}\text { Diabetes } \\
\text { mellitus }\end{array}$} & Yes & 3 & 64 & \multirow{2}{*}{3.06} & \multirow{2}{*}{$\begin{array}{l}0.67- \\
14.01\end{array}$} \\
\hline & No & 4 & 261 & & \\
\hline \multirow{2}{*}{$\begin{array}{l}\text { Severe } \\
\text { COVID- } \\
19\end{array}$} & Yes & 6 & 30 & \multirow{2}{*}{59} & \multirow{2}{*}{$\begin{array}{r}6.87- \\
506.56\end{array}$} \\
\hline & No & 1 & 295 & & \\
\hline
\end{tabular}

\section{Discussion}

Wang et al reported a median age of 51 years (range, 19-92 years); and 53.3\% cases as males in their study on 107 COVID-19 patients. The workers reported median time from first symptoms to hospital admission as 7 days (Inter Quartile Range 3.5-9); and a median length of hospital stay as 11 days (Inter Quartile Range 7- 15) [6]. Vellingiri et al reported fever, cough and dyspnoea as general symptoms in COVID-19 cases [10]. 
Kumar et al observed fever, fatigue, headache, cough, difficulty in breathing, and sore throat to be the commonest symptoms of COVID-19 [11]. Alfonso J et al reported fever (88.7\%, 95\%CI 84.5-92.9\%), cough $(57.6 \%, 95 \% \mathrm{CI} 40.8-74.4 \%)$ and dyspnea $(45.6 \%, 95 \%$ CI $10.9-80.4 \%)$ as the most prevalent clinical manifestations in their systematic review and meta analysis, while Umakantham et al reported non specific symptoms such as fever, cough and myalgia as the commonest symptoms $[2,12]$. These findings are similar to that of our study wherein the commonest symptoms were fever $(70.78 \%)$ and breathing difficulty $(28.01 \%)$

Table 5: Logistic regression analysis of severe COVID-19 by different independent variables

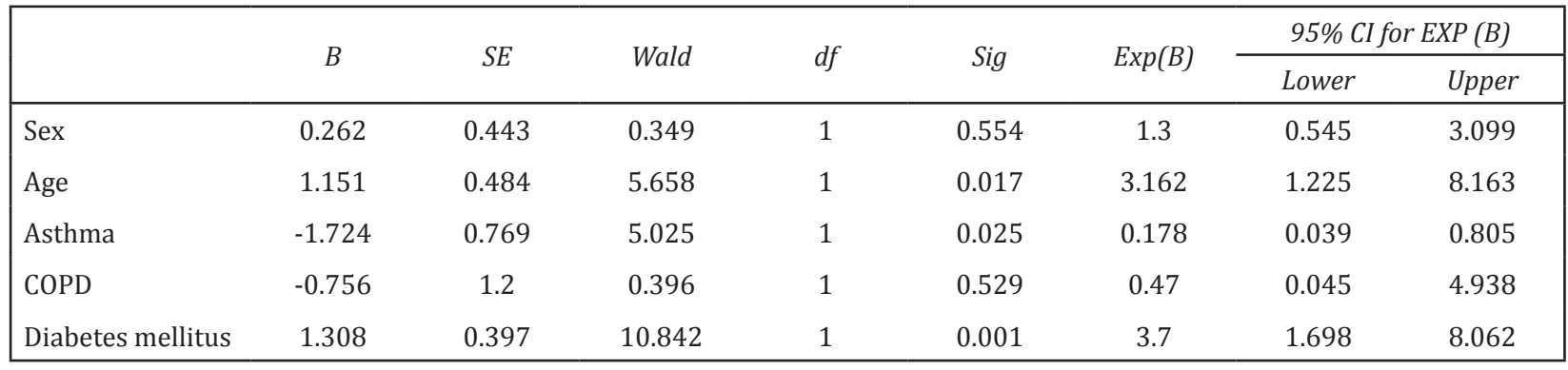

Zhang et al reported a higher mean duration of hospitalisation of 10.2 days as compared to 9.41 days in our study [1].

Vellingiri observed that high blood pressure, heart disease, lung disease, cancer or diabetes were the commonest comorbidities, while Umakanthan et al reported cardiovascular disease, lung disease, kidney disease or malignant tumours as the commonest comorbidities [9, 12]. Hypertension (26 [24.3\%]), cardiovascular disease (13 [12.1\%]), and diabetes (11 [10.3\%]) were the most common coexisting conditions in the study by Wang et al. Commonest symptoms reported at onset were fever (104 [97.2\%]), dry cough (67 [62.6\%]), fatigue (69 [64.5\%]), dyspnea (35 [32.7\%]), anorexia (33 [30.8\%]), and myalgia (33 [30.8\%]). Sore throat, headache, dizziness, abdominal pain, diarrhea, nausea, and vomiting were some of the less commonly reported symptoms [6].

Hua Li et al in their study on 138 COVID-19 hospitalized patients reported comorbidities with $31.2 \%$ (43) hypertension, $10.1 \%$ (14) diabetes, $14.5 \%$ (20) cardiovascular disease and 7.2\% (10) malignant [3]. Wen-Hsin et al in their study on 43 COVID-19 cases reported that $44 \%$ of COVID-19 cases had at least one comorbidity [5].

These findings are different from that of our study wherein Diabetes which was the commonest comorbidity was observed in sixty seven $(20.18 \%)$ of cases.
Ejaz et al reported that there was no significant association of SARS-CoV-2 with asthma [14]. These findings are different from that of our study wherein asthma was shown to have an association with severe COVID-19. Wang et al also reported that diabetics had a higher risk of exacerbation of COVID-19 (OR: 2.47, 95\% CI: 1.67-3.66, P<0.001) [15]. These findings are similar to that of our study. Wenjie Tian et al reported that older age (OR 15.6; 95\% CI 12.5-18.6, $\mathrm{P}<0.00001$ ), male sex (OR 1.8; 95\% CI 1.3-2.4, $\mathrm{P}=0.0003$ ) and diabetes (OR 2.0; $95 \%$ CI 1.7-2.3; $\mathrm{P}<0.00001)$ were associated with a higher risk of death due to COVID-19 [16]. Several workers have reported presence of diabetes to be significantly associated with severe COVID-19 as well as mortality due to COVID-19 [17-19].

These findings are different from that of our study wherein older age, and diabetes were significantly associated with severity of COVID-19.

Rodriguez-Moralesa et al also reported that at least one fifth of cases require supportive care in medical intensive care units; and a case fatality rate ranging from $11 \%$ to $15 \%$ [2]. These findings are different from our study wherein we observed that $36.14 \%$ required supportive care either in the form of oxygen or ventilator; and a case fatality rate of $2.10 \%$. Jain et al also reported a lower mortality rate due to COVID19 in India as compared to western countries, though the exact percentage mortality has not been specified by these workers [13]. 


\section{Limitations}

One of the major limitations of this study is that it is a cross sectional descriptive study. Our study has also shown an association between age more than seventy years and severe COVID-19, asthma and severe COVID-19; and diabetes and severe COVID19. However, since the study is a cross sectional descriptive study, the workers have been able to calculate the odds ratio both unadjusted and adjusted. Another limitation of this study is that Berkesonian bias (hospital bias) may have set in as only hospitalised cases of COVID-19 were included in the study.

\section{Conclusion}

Asymptomatic or flu-like symptoms such as fever, cough, myalgia, rhinorrhea, and sore throat, to acute respiratory distress syndrome (ARDS) or multiple organs failure constitute the wide range of clinical manifestations of COVID-19. Majority of the cases in our study shared similar clinical features and laboratory parameters. In majority of cases, COVID19 presents with a rapidly progressive course of fever, cough and dyspnea. Eliciting a history of recent travel to areas with ongoing outbreaks of SARS nCoV2 or contact with a confirmed case of COVID-19, should prompt clinicians to initiate isolation precautions and carry out laboratory confirmation. The workers recommend that more research be carried out to identify various agent, host and environmental factors which may play a significant role in the pathogenesis of severe and fatal infections.

\section{Conflicts of interest}

Authors declare no conflicts of interest.

\section{References}

[1] Zhang H, Shang W, Liu Q Zheng XZM, Yue M. Clinical characteristics of 194 cases of COVID-19 in Huanggang and Taian, China. Infection. 2020; 48:687-694.

[2] Rodriguez-Moralesa AJ, Cardona-Ospina JA, GutiérrezOcampoa E, Villamizar-Peñaa R, Holguin-Riveraa Y, et al. Clinical, laboratory and imaging features of COVID-19: A systematic review and meta-analysis. Travel Med Infect Dis. 2020; 34:101623.

[3] Li H, Liu Z, Ge J. Scientific research progress of COVID-19/ SARS-CoV-2 in the first five months. J Cell Mol Med. 2020; 24(12):6558-6570.

[4] Sheervalilou R, Shirvaliloo M, Dadashzadeh N, Shirvalilou S, Shahraki O, et al. COVID-19 under spotlight: A close look at the origin, transmission, diagnosis, and treatment of the 2019-nCoV disease. J Cell Physiol. 2020; 235(12):88738924.
[5] Wen-Hsin H, Meng-Yu C, Mao-Wang H, Chia-Hueu C, PoChang L, et al. Featuring COVID-19 cases via screening symptomatic patients with epidemiologic link during flu season in a medical center of central Taiwan. J Microbiol Immunol Infect. 2020; 53(3):459-466.

[6] Wang D, Yin Y, Hu C, Liu X, Zhang X, et al. Clinical course and outcome of 107 patients infected with the novel coronavirus, SARS-CoV-2, discharged from two hospitals in Wuhan, China. Critical Care. 2020; 24(1):188.

[7] Ye Z, Zhang Y, Wang Y, Huang Z, Song B. Chest CT manifestations of new coronavirus disease 2019 (COVID19): a pictorial review. Eur Radiol. 2020; 30 (8):4381-4389.

[8] Huang X, Wei F, Hu L, Wen L, Chen K. Epidemiology and Clinical Characteristics of COVID-19. Arch Iran Med. 2020; 23(4):268-271.

[9] Revised guidelines for Home Isolation of very mild/presymptomatic COVID-19 cases. https://www.mohfw.gov.in/ pdf/ Revised guidelines for Home Isolation of very mild presymptomatic COVID19cases 10May2020.pdf

[10] Vellingiri B, Jayaramayya K, Iyer M, Narayanasamy A, Govindasamy V, et al. COVID-19: A promising cure for the global panic. Sci Total Environ. 2020; 725:138277.

[11] Kumar M, Tak K, Gahlot R, Sharma A, Dhangar K. A chronicle of SARS-CoV-2: Part-I - Epidemiology, diagnosis, prognosis, transmission and treatment. Sci Total Environ. 2020; 734:139278.

[12] Umakanthan S, Sahu P, Ranade AV, Bukelo MM, Rao JS, et al. Origin, transmission, diagnosis and management of coronavirus disease 2019 (COVID-19). Postgrad Med J. 2020; 96(1142):753-758.

[13] Jain VK, Iyengar K, Vaish A, Vaishya R. Differential mortality in COVID-19 patients from India and western countries. Diabetes Metab Syndr. 2020; 14(5):1037-1041.

[14] Ejaz H, Alsrhani A, Zafar A, Javed H, Junaid K, et al. CoVID-19 and comorbidities: Deleterious impact on infected patients. J Infect Public Health. 2020; 13(12):1833-1839.

[15] Wang B, Li R, Lu Z, Huang Y. Does comorbidity increase t1he risk of patients with COVID-19: evidence from metaanalysis. Aging (Albany NY). 2020; 12(7):6049-6057.

[16] Tian W, Jiang W, Yao J, Nicholson CJ, Li RH, et al. Predictors of mortality in hospitalized COVID-19 patients: A systematic review and meta-analysis. J Med Virol. 2020; 92(10):18751883.

[17] Gold MS, Sehayek D, Gabrielli S, Zhang X, McCusker C, et al. COVID-19 and comorbidities: a systematic review and metaanalysis, Postgrad Med. 2020; 132(8):749-755.

[18] Kumar A, Arora A, Sharma P, Anikhindi SA, Bansal N, et al. Is diabetes mellitus associated with mortality and severity of COVID-19? A meta-analysis. Diabetes Metab Syndr. 2020; 14(4):535-545.

[19] Pathangey G, Fadadu PP, Hospodar AR, Abbas AE. Angiotensin-converting enzyme 2 and COVID-19: patients, comorbidities, and therapies. Am J Physiol Lung Cell Mol Physiol. 2021; 320(3):L301-L330. 